\title{
Preservation of Minangkabau Local Wisdom as Media for Cultural Literacy
}

\author{
Malta Nelisa ${ }^{1, *}$ Ardoni $^{1}$ Yulianti Rasyid ${ }^{1}$ \\ ${ }^{1}$ Indonesian Language Department, Universitas Negeri Padang, Padang, Indonesia \\ *Corresponding author. Email: malta@fbs.unp.ac.id
}

\begin{abstract}
Information on local wisdom is important to be preserved for the sustainability of people's lives and the natural environment. This study aims to identify and describe Minangkabau local wisdom, describe forms of Minangkabau local wisdom, and describe efforts to preserve information on Minangkabau local wisdom as a medium of cultural literacy. Minangkabau is a tribe that inhabits the province of West Sumatra which has a matrilineal kinship system. The original territory of the Minang people is known as Luhak which consists of Luhak Agam, Luhak Tanah Datar, and Luhak 50 Kota, each of which is currently called a district. This study is qualitative research with a descriptive method. Data collection using purposive sampling technique with the criteria of informants are traditional stakeholders or people who are elders and understand the local wisdom of the local area to local attractions. Through the results of the study found 27 tourism objects with 44 local wisdom. The forms of local wisdom identified are related to agricultural systems, medicine, use of natural resources, traditions, architecture, clothing, and social relations. Conservation efforts as cultural literacy, namely packaging information on local wisdom into a Minangkabau database that can be accessed later by everyone.
\end{abstract}

Keywords: Knowledge preservation, Local wisdom, Cultural literacy, Minangkabau

\section{INTRODUCTION}

Tourism objects in West Sumatra are currently experiencing an increase in terms of quantity, both nature tourism and tourism designed by the community. Tourist information is obtained by the public from various media, especially media based on information technology. The presence of information technology on the other hand describes the influence on the culture of the local community. Slowly the original culture began to shift to modern culture. Without realizing it, it is feared that over time it will eliminate the original culture, especially the Minangkabau people.

Minangkabau refers to a cultural entity that geographically inhabits the area of West Sumatra. The Minang people are known to use a matrilineal kinship system, namely the kinship system following the mother's lineage. In terms of territory, the Minang people come from an area called Luhak, namely Luhak Agam, Luhak Tanah Datar, and Luhak 50 Kota which is currently an area called a Regency.

This study aims to identify and describe Minangkabau local wisdom found around tourism objects, describe forms of Minangkabau local wisdom, and describe efforts to preserve information on local wisdom as a medium of cultural literacy. Local wisdom is the noble value that applies in the life of the community too, among others, to protect and manage the environment in a sustainable manner [1]. Another opinion explains that indigenous knowledge is the knowledge that is unique in a society or culture which includes cultural traditions, values, beliefs, and views of local communities, including certain beliefs and rules as part of the customs of a community group [2]. Local wisdom is also defined as a way or practice developed by a group of people and comes from an understanding of the environment that is formed from living in that place for generations [3]. Local wisdom is closely related to the use of nature by the community on the condition that it maintains environmental sustainability. In addition, the use of nature by local communities is often related to traditions that have been used and held by the community for generations. This includes the Minangkabau community.

In terms of its form, local wisdom is divided into tangible and intangible. In terms of type, local wisdom 
is divided into belief, local wisdom in health, local wisdom and human resources, technology, educational processes, communication, agriculture, food-producing technology, and arts and skills [4]. Various forms of local wisdom are practiced by the Minangkabau community, but until now there have been no media that has collected this information.

The study of local wisdom is closely related to the preservation or preservation of local knowledge which aims to maintain the traditional values and culture of the local community. Knowledge preservation consists of three activity processes, namely: selection, storage, and actualization [5]. Through this stage, it can be seen the forms of local wisdom that have been applied by the Minangkabau community from generation to generation.

The results of the identification of local wisdom are the capital in preserving the culture and traditions of the community. This information can be used as a medium in cultural literacy. Cultural literacy requires interaction with culture and reflects on that culture. Cultural literacy is rooted in a wide variety of knowledge used to establish communication, acceptance, and understanding in a dynamic global society [6].

\section{METHOD}

This research is a qualitative study with an ethnographic approach, which uses a cultural preservation point of view as an attempt to describe Minangkabau local wisdom. The research sample was determined by purposive sampling technique with the criteria of local wisdom found in tourist objects or local wisdom found in the area around tourist objects in the Minangkabau region. This research is limited to the Luhak nan Tigo area (Tanah Datar, Agam, and 50 Kota).

The initial stage of the research was carried out by identifying and documenting tourist objects in the Minangkabau area for the Luhak nan Tigo. Next, identify and describe local wisdom that is a tourist object and local wisdom found in the area around the tourist attraction. The results of the description of local wisdom data are packaged into cultural literacy media in the form of information products of Minangkabau local wisdom.

Data collection was carried out by observation, interviews, and literature study. The research data analysis was carried out by using the triangulation method, namely data, theory, and researchers. Data on tourism objects and local wisdom were described using the theory of preservation of knowledge, local wisdom, and cultural literacy. The role of the next researcher is to present data analysis for the concept of tourism development.

\section{DISCUSSION}

The results of this study explain three things, namely the identification of local wisdom, types of local wisdom, and efforts to preserve local wisdom as a media for Minangkabau cultural literacy.

\subsection{Description of Minangkabau Local Wisdom}

The results of the identification of Minangkabau local wisdom in three areas of Minangkabau Luhak nan Tigo which are adjacent to tourist attractions are as follows.

\subsubsection{Local Wisdom in Luhak Tanah Datar}

The tourist objects found in Luhak Tanah Datar from the identification results are the Sari Tabek Traditional Hall, Singkarak Lake, Kubu Gadang Tourism Village, Pagaruyuang Palace, Long Graveyard, Nagari Tuo Pariangan, Pato Peak Panorama, and the Minangkabau Cultural Information Documentation Center (PDIKM). The local wisdom found in this area is as follows.

The tourist attraction of the Sari Tabek Traditional Hall is also a form of local wisdom in the form of architecture. A traditional hall is a place for community activities that is usually used by traditional stakeholders to discuss and hold traditional ceremonies. This building is made of wood and roofed with palm fiber which has six gonjong and a stage floor. This building is elongated without walls which aims to allow the wider community to attend meetings held by the Pangulu. Continuous interaction is built on the needs of the community, including through decision-making by deliberation between the leadership and the nagari residents. The following figure is the structure of the Sari Tabek Traditional Hall. 


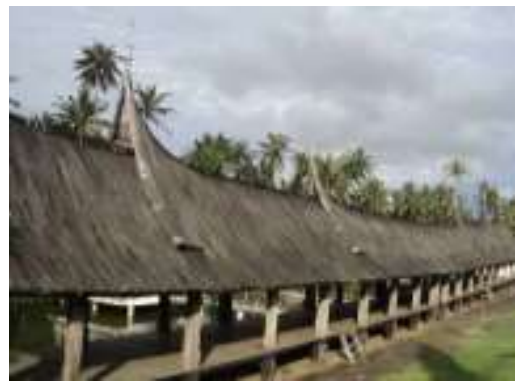

Figure 1 Sari Tabek Traditional Hall, Local Wisdom in Architectural Form

Other local wisdom is around Lake Singkarak tourism object in the form of tradition, namely the tradition of pacu biduak. This tradition is a traditional sport that takes place on Lake Singkarak using a small canoe called a biduak. This area is also famous for its silek tradition in the water. Lake Singkarak is also famous for producing Bilih fish, so this endemic animal is processed into various special foods such as fried fish and pangek.

In the Kubu Gadang Tourism Village, there is a baronde local wisdom. The activities are carried out by eating together in the middle of the rice fields accompanied by several art attractions such as dances, theatrical performances, and nagari children's games. There is also a tradition of eating bajamba, which is eating together in one large dining area. In the same area but in different villages, there is a similar tradition called the baradaik eating tradition, which is eating in the middle of the rice fields using banana leaves. Another tradition is silek lanyah, which is martial arts performed in the middle of a muddy puddle. All these traditions are carried out as entertainment for the community to be grateful for the pleasures of harvesting rice.

The Tanah Datar area is also famous for the Malamang tradition when commemorating the Prophet's Birthday. Another typical food is the kawa leaf drink which is a drink made from coffee leaves. The presentation is typical using coconut shells that are halved. In this area, the Pacu Jawi (cow race) ceremony is also held annually to celebrate the rice harvest as well as a folk festival for the local community.

\subsubsection{Local Wisdom in Luhak Agam}

Luhak Agam has tourist attractions including Aia Tigo Raso, Maninjau Lake, Janiah River Milky Fish, Amai Setia Crafts, Japang Hole, Pincuran Gadang
Mosque, Nagari Koto Gadang, Ngalau Alam Tabik, Lawang Peak, Bung Hatta Birth House, Tabek Gadang Sungai Tanang, and Tarusan Kamang. The local wisdom found in this area is as follows.

Aia Tigo Raso tourism object is also local wisdom for the local community because this water has three different springs and is used for treatment. Another local wisdom is the tradition of rakik-rakik in the Lake Maninjau area which is held once a year. This tradition is complemented by the art of Tambua Tansa. In this area, there is also local wisdom for breeding fish on the outskirts of Lake Maninjau called Rasau. Lake Maninjau is also famous for producing fish called rinuak which is processed by local people into various special foods such as bakwan, pepes, and peyek.

Another Agam area that has local wisdom is in the Janiah River Milky Fish tourism object. This fish pond never stops releasing water, so it is also used by the community to irrigate rice fields. In the same area, there is Amai Setia Handicraft which is a livelihood for especially mothers in making crafts such as embroidery, weaving, lace, veils, metal, and silver crafts. In the Pincuran Gadang area, people take advantage of the natural products of pumpkins to make various special foods made from pumpkins. In terms of tradition, the Agam district is famous for its traditional silek which is passed down from generation to generation, and the bacorotai tradition, which is catching fish with your bare hands at Tabek Gadang. This tradition is held once a year to entertain the public.

\subsubsection{Local Wisdom in Luhak 50 Kota}

Luhak 50 Kota have many tourist attractions, including the Harau Valley, Batu Balah, Kapalo Banda Taram, Lubuak Bulan, Kudo Kubu Gadang Pacu, and the Rumah Godang of Baringin River. Around these attractions, there is a lot of local wisdom that has been passed down from generation to generation by the community.

Local wisdom in this area includes the tradition of silek lanyah, which is a silat movement that is carried out on wet soil or mud. Furthermore, there is the tradition of alek bakajang, which is a boat that sails down the river to the accompaniment of the typical talempong of Nagari Gunuang Malintang. Another tradition is that Pacu Kudo is held at the Kubu Gadang Arena, Payakumbuh City as a routine sport for the younger generation in the city. The implementation of these traditions is usually accompanied by traditional 
arts such as randai, silek, and rabab. In addition to art, this event will also offer traditional foods such as randang pucuak kopi, batiah, and bareh randang.

\subsection{Types of Local Wisdom in Minangkabau}

Types of local wisdom is divided into belief, local wisdom in health, local wisdom and human resources, technology, educational processes, communication, agriculture, food-producing technology, and arts and skills.

First, local wisdom in the form of trust. This is found in the Agam Regency, namely the community's belief in the existence of the Janiah River Milky Fish which is believed by the community to have been breeding for hundreds of years in the river and left there to maintain the balance of nature in the area.

Second, local wisdom in health is found in the tourist area of Aia Tigo Raso. The tradition of drinking and bathing with mini kola water is believed by the community to be able to cure various diseases, but specifically, the pool water is used for eye health.

Third, local wisdom and human resources are found in the Amai Setia Craft area. In this area, the community, especially women, are able to produce various kinds of crafts that can improve the community's economy for the better. This location has become one of the tourist destinations as a form of handicrafts typical of the Minang realm.

Fourth, local wisdom in the form of technology is found in the area around Lake Maninjau. The community uses rasau for fish breeding which is placed on the outskirts of Lake Maninjau. Rasau serves as a fish pond which is harvested once every three months.

Fifth, local wisdom in communication is the existence of the Sari Tabek Traditional Hall. This architecture is used by the community as a place to discuss, express opinions, as well as hold traditional activities that can be witnessed by the community. This is a place to communicate customary rules and activities from traditional stakeholders to the community.

Sixth, local wisdom in terms of food production. The Minang people are well known for their delicious and varied food and drink. From the results of the identification, it was found that there are many types of special foods that have been produced from generation to generation by people in various areas of Minangkabau. These foodstuffs come from natural resources available in each region. Among the typical foods and drinks are bilih fish, food made from rinuak, rakik maco, pangek simawang, lamang tapai, dadiah, kawa daun, kabaka rice, pumpkin and peanut-based foodstuffs, kapau rice, ramas rice, galamai, batiah, bareh randang. randang pucuak kopi, and itiak lado mudo.

Seventh, local wisdom is related to art and skills. This type of local wisdom is among the most diverse in the Minangkabau region. Minangkabau traditional arts are spread throughout the Minangkabau region. The form of this tradition sometimes has similarities with other areas in the Minangkabau region, but sometimes the philosophy and series of activities are displayed in different forms. Among the traditional arts found from the identification results are: the tradition of pacu biduak, pacu upiah, pacu kudo, rakik-rakik, bakajang, bacorotai, silek lanyah, randai, tambua tansa art, rabab, eating bajamba, and eating baradaik.

Most of this type of local wisdom is still practiced and organized by the community. However, some of them are rarely seen. Therefore, documenting local wisdom information is one way to maintain local wisdom, especially those scattered in various areas in Minangkabau.

\subsection{Preservation of Local Wisdom Information as a Media of Cultural Literacy}

The results of the identification of local wisdom have use-value if the stages in the preservation of knowledge are carried out in full. One of the efforts to document local wisdom information is to create an information package for Minangkabau local wisdom. This product can be accessed in print or electronically. The cultural literacy of the community can be improved through the provision of various information media with Minangkabau cultural content through this information product. Information packaging is made in such a way as to provide free access for the community to explore various information on Minangkabau local wisdom. Efforts made in preserving local wisdom are by providing cultural literacy media as follows.

First, local wisdom information products in digital format in the form of ebooks that are accessed in the form of flipbooks. 


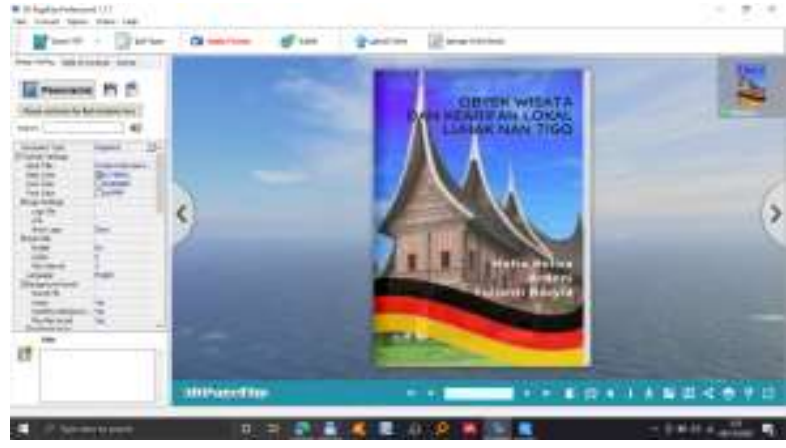

Figure 2 Ebook Front Page Display of Minangkabau Local Wisdom

Figure 2 shows the results of data entry in PDF format to flipbook format. In this view, there are several features for the next step in making information products. In several other sections, namely on the far left, there is basic information or information about the framework for making flipbooks. The image from the conversion results displays the front page of the ebook or cover.

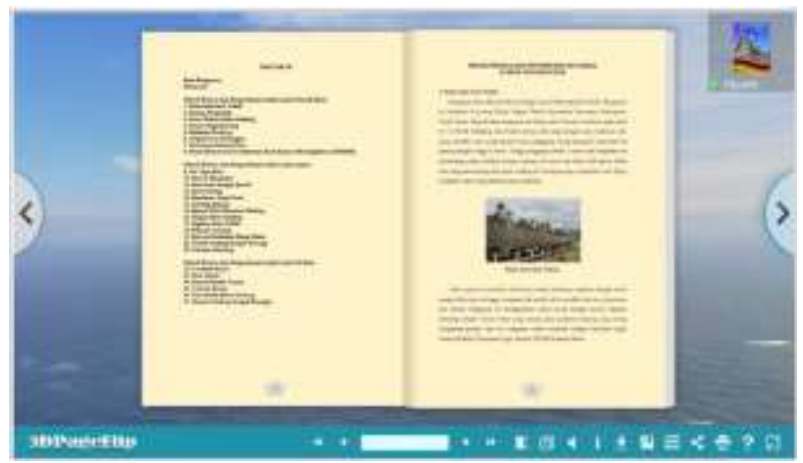

Figure 3 Flipbook Fullscreen Display on Application

Figure 3 shows this page of information products, namely the table of contents and description pages of tourist attraction information and local wisdom. This information page about tourism objects and local wisdom contains 27 tourism objects that have been identified in the previous stage. The arrangement of this page is sorted from tourism objects and local wisdom in Luhak Tanah Datar, then Luhak Agam, and finally Luhak 50 Kota. Sorting information is made alphabetically by the name of the tourist attraction. This information is also equipped with pictures or photos of each tourist attraction and local wisdom.

Second, the dissemination of information on local wisdom through the Minangkabau database. In this study, a database has been designed that contains various Minangkabau local wisdom. This database is expected to provide flexibility for the public in accessing Minangkabau information. It is hoped that in the future it will not only be about local wisdom but about all things related to Minangkabau information. The following figure is an image of the local wisdom database of the Minangkabau community.

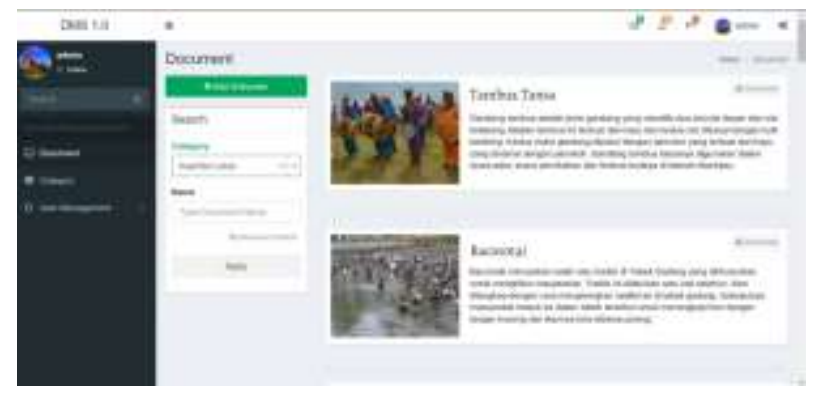

Figure 4 Minangkabau Database Design View

This digital information product is expected to make it easier for the public to access information on tourism objects and local wisdom, especially those in Tanah Datar, Agam, and 50 Kota. This ease of access to information can support the efforts of various groups who care about the preservation of culture and the natural resources that accompany it so that the Minangkabau people, in particular, do not lose their identity as Minang people and can maintain their customs and culture even though developments in various fields and cultures continue to modernize society. This product is a Minangkabau cultural literacy media whose contents can be added and developed in line with input on information on Minangkabau local wisdom.

\section{CONCLUSION}

Preservation of information on Minangkabau local wisdom produces an information product that is in line with the development of information technology. This product is a media for Minangkabau cultural literacy, especially for the younger Minang generation who may not know much about local wisdom in their area. Efforts to create media literacy are important in efforts to preserve local wisdom. This media is expected to be used by various parties wisely so that Minangkabau local wisdom is maintained and implemented in the midst of Minangkabau society which has undergone modernization. 


\section{ACKNOWLEDGMENTS}

We thank our colleagues from the Department of Indonesian Language and Literature Universitas Negeri Padang who provided insight and expertise that greatly assisted the research.

\section{REFERENCES}

[1] Indonesia. Undang-Undang Republik Indonesia Nomor 32 Tahun 2009 Tentang Perlindungan dan Pengelolaan Lingkungan Hidup. https://jdih.esdm.go.id/storage/document/UU\%203 2\%20Tahun\%202009\%20(PPLH).pdf

[2] M. Giorgia. 2016. Indigenous Knowledge and Implications for the Sustainable Development Agenda. European Journal of Education: Research, Development, and Policy. 52(4): 437 447.

https://onlinelibrary.wiley.com/doi/pdf/10.1111/eje d.12238.

[3] E. A. Meinarno, B. Widianto, and R. Halida. Manusia dalam Kebudayaan dan Masyarakat. Jakarta: Penerbit Salemba, 2015.

[4] A. M. Kaniki, and M. E. Mphalele. . Indigenous Knowledge for the Benefit of All: Can Knowledge Management Principles be Used Effectively? South African Journal of Libraries and Information Science, 2002, 68 (1): 1 - 15, 2002. Available from https://journals.co.za/docserver/fulltext/liasa/68/1/1 iasa_v68 n1_a1.pdf?expires $=1601214812 \& i d=i d \&$ accname $=$ guest $\&$ checksum $=256$ A18A73B3CF997 7779C3920F84D0A7

[5] R. Agrifoglio. Knowledge Preservation Through Community of Practice: Theoretical Issues and Empirical Evidence, 2015 London: Springer.

[6] G. B. Aprinta. Fungsi Media Online sebagai Media Literasi Budaya bagi Generasi Muda. The Messenger, $2013 . \quad 5 \quad$ (1): $16 \quad-30$. http://journals.usm.ac.id/index.php/themessenger/article/view/218/165. 